
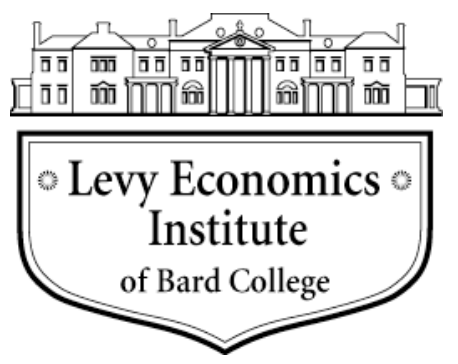

Working Paper No. 669

\title{
Race, Power, and the Subprime/Foreclosure Crisis: A Mesoanalysis
}

by

\section{Gary A. Dymski}

University of California, Riverside

Jesus Hernandez

University of California, Davis

\section{Lisa Mohanty* \\ TUI University}

May 2011

*Correspondence: gary.dymski@ucr.edu; jchernandez@ucdavis.edu; lisa_moh@yahoo.com.

The Levy Economics Institute Working Paper Collection presents research in progress by Levy Institute scholars and conference participants. The purpose of the series is to disseminate ideas to and elicit comments from academics and professionals.

Levy Economics Institute of Bard College, founded in 1986, is a nonprofit, nonpartisan, independently funded research organization devoted to public service. Through scholarship and economic research it generates viable, effective public policy responses to important economic problems that profoundly affect the quality of life in the United States and abroad.

Levy Economics Institute P.O. Box 5000

Annandale-on-Hudson, NY 12504-5000

http://www.levyinstitute.org 


\begin{abstract}
Economists' principal explanations of the subprime crisis differ from those developed by noneconomists in that the latter see it as rooted in the US legacy of racial/ethnic inequality, and especially in racial residential segregation, whereas the former ignore race. This paper traces this disjuncture to two sources. What is missing in the social science view is any attention to the market mechanisms involved in subprime lending; and economists, on their side, have drawn too tight a boundary for "the economic," focusing on market mechanisms per se, to the exclusion of the households and community whose resources and outcomes these mechanisms affect. Economists' extensive empirical studies of racial redlining and discrimination in credit markets have, ironically, had the effect of making race analytically invisible. Because of these explanatory lacunae, two defining aspects of the subprime crisis have not been well explained. First, why were borrowers that had previously been excluded from equal access to mortgage credit instead super included in subprime lending? Second, why didn't the flood of mortgage brokers that accompanied the 2000s housing boom reduce the proportion of minority borrowers who were burdened with costly and ultimately unpayable mortgages? This paper develops a mesoanalysis to answer the first of these questions. This analysis traces the coevolution of banking strategies and client communities, shaped by and reinforcing patterns of racial/ethnic inequality. The second question is answered by showing how unequal power relations impacted patterns of subprime lending. Consequences for gender inequality in credit markets are also briefly discussed.
\end{abstract}

Keywords: Race; Ethnicity; Subprime Mortgages; Discrimination; Redlining; Foreclosures; Power; Mesoanalysis

JEL Classifications: B50, G21, G28, J15, J16, P16, R31 


\section{INTRODUCTION: RECENTERING THE POLITICAL ECONOMY OF THE SUBPRIME CRISIS}

Despite the avalanche of academic research that the subprime crisis has unleashed across several disciplines, gaps and disjunctures have arisen and persisted in these studies' coverage.

Sociologists, geographers, and urban scholars have emphasized the connection between race and space in the subprime crisis. The main line of argument is that residential segregation-fortified by years of racial redlining and discrimination, as well as banks' withdrawal from minority neighborhoods-led to the concentration of subprime lending in minority areas. So home-loan lending over the years amplified spatial racial disparities, subprime lending exploited them, and consequently the foreclosure crisis has disproportionately affected minority homeowners. The economics literature has, by contrast, ignored the fact that subprime lending emerged as one of several forms of "predatory lending," targeting African Americans and Latinos. Economists have grounded their explanations instead in the incentives and behaviors of the institutions and markets that generated and distributed subprime credit. This has led them to trace the subprime crisis to human fallibility: over-optimistic assessments of housing-price trajectories; and the inability of financial authorities to either prevent unwise lending or to compel borrowers to repay. The disproportionately minority and female subprime borrowers were less victims than they were either myopic or overly greedy and over-reaching (or both). Similarly, economists have thus far ignored the links between the foreclosure wave, subprime lending, and racial inequality and segregation.

This explanatory rift can be traced to two sources: first, limitations in the way that both approaches define the boundaries of market mechanisms ("the economy") and the economic sphere; second, inattention to the exercise of power in market outcomes. Most economists' analytical frame does not include the structure of social relations that shape the risk and return that provide the raw material for instruments with different risk/return combinations. And noneconomists' analyses of the subprime crisis generally do not explore market mechanisms. This paper attempts to re-center the political economy of the subprime crisis by focusing attention on these two elements.

Remedying both perspectives' lacunas will require shifting the boundaries of the economic: for economists, stretching it beyond the pure mechanics of disembodied, asocial 
choice; for non-economists, making economic mechanisms visible as social practices. This shifting of boundaries will permit contributors to both literatures to explore the now-missing links between racial inequality and market mechanisms. As Acker (2000, page 192) puts it, "class, along with gender and race, are best seen as active practices rather than as classificatory categories ... 'the economic' must be expanded to understand the life situations of women and people of color."

What is missing here is what Elson (1994) and others have called the "meso" level of analysis: attention to the social construction of the institutional mechanisms whereby subprime loans were created and distributed, or to the mechanisms that govern foreclosure processes. Bringing in this level of analysis permits an investigation of how market power was attained and used in the long history of the social exclusion of minorities from equal access to housing and mortgage credit.

\section{Roadmap}

We precede as follows. Section 2 sets out economists' principal lines of argument about the subprime and foreclosure crisis. Section 3 summarizes some of the evidence about the links between racial inequality, subprime lending, and foreclosures. It goes on to show how some social theorists have identified racial segregation itself as the root of these twin crises. Section 4 then show why, for many economists, a substantial empirical literature has not succeeded in showing that minorities have been systematically disadvantaged in mortgage markets for reasons unrelated to racial/ethnic differences in creditworthiness.

Sections 5 and 6 then respond both to social scientists' failure to identify how markets generate racially-unequal subprime outcomes, and to economists' doubts that that racial/ethnic inequality matters in the subprime crisis. The pervasive effects of racial inequality in multiple markets, combined with ineffective regulation, created incentives for banks to maximize shortterm profits by pushing subprime lending, especially in minority communities, where banks controlled the choke-points of a lending complex. Banks' use of market power cannot be captured by seeking out instances of individual-level discrimination; instead, it built on the legacy of the racial cartel that had created segregated urban space in the mid- $20^{\text {th }}$ century, and on the more recent decades of financial exclusion. Section 7 summarizes our findings. 


\section{ECONOMISTS' PERSPECTIVES: MORAL HAZARD, UNCERTAINTY, SUBPRIME CRISIS}

Many economists view financial markets as the locus of efficient, information-rich exchanges, providing a wide range of financing and savings options. In this perspective, subprime lending is understood as denoting a set of mortgage instruments tailored for high-risk borrowers and carrying above-market expected returns. High-risk lending and borrowing is consistent with well-functioning markets as long as borrowers and lenders are subject to market discipline and are adequately regulated.

When markets break down, as did the subprime markets in late 2007, attention immediately centers on bad behavior by participants in the affected market(s), inadequate government regulation of market relations, or unwanted government interference. For example, Quigley (2008) explores two possibilities: first, unscrupulous players could exploit the unwary and naive in under-regulated markets; second, people can be systematically fooled when caught in an asset bubble. The idea that market participants can be fooled or can fool themselves is a timeless theme in financial history, as Reinhart and Rogoff (2009) point out; their acclaimed volume asserts that economists should use the same tools in analyzing the subprime/housing-bubble crisis as would be used in explicating any financial crisis.

In this view, human fallibility chronically undermines financial markets' efficiency. This fallibility, in turn, involves two interacting elements: the breakdown of optimistic assessments of future returns for the assets on which loans are based, and the inability of financial authorities to either prevent unwise lending or to compel borrowers to repay (ibid., Chapter 4). Some economists emphasize the former element. Breakdowns in beliefs and confidence (Wray 2008), or even selffulfilling prophecies (Farmer 2010), can burst an asset bubble and destabilize any set of market structures and regulatory precautions. For example, in a detailed exploration, Gerardi et al. (2009) attribute the subprime crisis to the underestimation of the likelihood that housing prices might fall by many participants in many interlinked markets.

Other analysts downplay expectational errors and instead emphasize perverse market incentives or regulatory flaws. In this view, moral hazard leads agents to take too many risks when they are insufficiently fearful of adverse outcomes. Lewis (2010) argues, for example, that subprime 
securities markets were under-regulated, the participants were undercapitalized, and bond-market bonus mechanisms encouraged excessive risk-taking. Some economists have argued that governmental subsidies for risky loans injected moral hazard into subprime lending (for example, Calomiris 2008).

Economists' dissections of subprime lending and the subprime crisis have largely paid virtually no attention to racial discrimination, redlining, or predatory lending. Shiller (2008), for example, makes no mention of these topics in a book-length discussion. The most notable exception is the contrarian assertion by Wallison (2009) that the Community Reinvestment Act (CRA) has forced banks to make home loans to borrowers with low incomes. ${ }^{2}$

Economists' writings about the subprime crisis have instead focused on market mechanisms, with debate unfolding along familiar dividing lines. Analyses of incentive and governance problems are sufficient to generate a robust debate about "what went wrong," without bringing in social factors such as racial discrimination. Indeed, economists introducing racial/ethnic inequality into models designed to communicate with other economists are at risk of disqualifying themselves from influencing the modeling conventions of post-crisis models of the credit market.

\section{SOCIAL-THEORY PERSPECTIVES: RACE, SPACE, AND THE SUBPRIME/FORECLOSURE CRISIS}

Unfolding as if in a parallel world, studies in several other disciplinary fields have developed analyses of the subprime and foreclosure crises that emphasize their roots in historical and contemporary practices that generate and reinforce racial inequality. Not all analyses of the current financial crisis by non-economist social theorists give pride of place to racial inequality and predatory lending, in part because of its extreme variability across space (Aalbers 2009). Nonetheless, the contrast with economists' analyses is dramatic.

In 2004, McCoy and Wyly edited a special issue of Housing Policy Debate on predatory lending which emphasized its links with racial inequality and segregation. Wyly et al.(2008)

\footnotetext{
2 This argument, which ignores the fact that CRA advocates fought the spread of subprime lending, has been forcefully debunked-see, for example, Laderman and Reid (2008)-and is not discussed further here.
} 
showed that predatory lending was concentrated in cities with large concentrations of minorities. Squires et al. (2009) and Rugh and Massey (2010) too have pointed out the strong correlation between residential segregation and subprime lending. The latter authors have asserted that racial/ethnic segregation is the root cause of the crisis. These authors use a two-stage least squares model to confirm "the causal effect of black segregation on the number and rate of foreclosures across metropolitan areas" along with "overbuilding, risky lending practices, lax regulation, and the bursting of the housing price bubble" (page 629). Immergluck, Aalbers, and Marcuse (2009) argue that minority communities were subjected to subprime-loan pushing by a vertically-integrated housing-finance system. Crump et al. (2008) summarize many of the findings of these and related articles when they write:

"Low-income and racially marginalized neighborhoods, once redlined and excluded from mainstream credit markets, were at the center of the profitable wave of subprime abuse and equity extraction during the long housing boom, and are now at the center of the long, slowly unfolding catastrophe of the U.S. foreclosure crisis." (page 745)

Several key points from this literature are especially important for the analysis developed below. subprime/foreclosure crisis. First, subprime loans were already growing rapidly in the 1990s in minority neighborhoods (HUD 2000). From the start, African Americans and Latinos were about twice as likely to receive subprime home loans as were whites (Bradford 2002). For example, in a study of subprime lending in Baltimore for the period 1998-2002, Wyly et al. (2006) found substantial evidence of racial targeting, even after controlling for a variety of supply and demand factors in the subprime securitization market; further, subprime loans were concentrated in segregated neighborhoods. Second, subprime lending continued to grow in "subprime zip codes" even as income levels there declined in the 2002-2005 period (Mian and Sufi 2008).

Third, subprime lending accounted for 43 percent of the increase in black home ownership during the 1990s and 33 percent of the growth in ownership within minority neighborhoods (Williams et al. 2005) a pattern that continued through the 2007 subprime crisis. Been, Ellen, and Madar (2009) find, for 2006 national data, that African American loan applicants are 2.8 times more likely to get a high-cost loan than is a white in a low-segregation city, but (respectively) 3.5 or 3.4 times more likely in a highly-segregated city. Avery, Brevoort, and Canner (2007) find that most of the disparity in the racial distribution of prime and subprime mortgages can be traced to the higher rate at which African-Americans and Latinos 
obtain mortgages from (unregulated) mortgage-brokers, not from (regulated) depository institutions. This is linked to the paucity of depository branches in African-American and Latino neighborhoods (Dymski and Mohanty 1999). Concentrated subprime lending, in turn, crowds out non-subprime lending and reduce loan-product choice for all residents (CRC et al. 2010).

Fourth, mortgage-payment pressures led to foreclosure problems in minority neighborhoods well before the housing bubble peaked in late 2006. Schloemer, Li, et al. (2006) examined six million subprime mortgages made between 1998 and 2004 and find that "despite .. a favorable economic environment during the past several years, the subprime market has experienced high foreclosure rates comparable to the worst foreclosure experience ever in the modern prime market" (page 2). The reason is that subprime borrowers disproportionately face repayment problems. These authors also find, however, that distressed prepayments are "substitutes" for foreclosures in strong housing markets: in markets with strong housing appreciation, these borrowers could refinance under duress; in stagnant markets, they were forced into foreclosure. ${ }^{3}$ Of course, refinancing into a new subprime mortgage forestalls, but doesn't eliminate, household financial pressure. Once these market flipped from priceappreciation to stagnation or decline, foreclosures were certain to grow explosively. Indeed, a Massachusetts study (Gerardi and Willen 2009) finds minority homeownership obtained via subprime mortgages proved "exceptionally unstable in the face of rapid price declines ... subprime lending did not, as commonly believed, lead to a substantial increase in homeownership by minorities but instead generated turnover in properties owned by minority residents" (page 1). And as Immergluck and Smith (2006) pointed out, foreclosures have large spillover impacts on housing prices and the social life of surrounding neighborhoods. The spatial concentration and contractual instability of subprime loans was one reason, in turn, that the fallout from the collapse of housing prices after 2006 spread unevenly over the urban landscape (Immergluck 2008).

These findings all underline the cumulative consequences of racially-differential lending processes for minority communities. Nonetheless, researchers developing these findings have been careful to emphasize that their elaborations of differential socio-economic conditions do not constitute proof that economic mechanisms are specifically biased against racial/ethnic-

\footnotetext{
${ }^{3}$ Specifically, for 1998-2002 loans, these authors found that a 1\% decrease in housing-price appreciation was associated with a $7 \%$ increase in foreclosures and a $3 \%$ decrease in distressed prepaid loans.
} 
minority individuals. Emblematic is this summary paragraph from Been, Ellen, and Madar (2009 page 20):

\footnotetext{
"While our results suggest that racial segregation may exacerbate racial disparities in high cost lending, our data cannot reveal why these associations exist. Our findings for New York City, however, are consistent with mechanisms that depend on differences in access to credit markets by neighborhood, such as access to bank branches, differences in social networks across neighborhoods, and racially discriminatory geographic targeting by high cost lenders, which would impact residents of all races in these neighborhoods. It appears that residents of neighborhoods with higher shares of black residents are particularly disadvantaged."
}

An earlier sentence from these authors clarifies this caveat:

"To date, little empirical research has been able to demonstrate the distinct role of targeting in racial disparities in mortgage outcomes, but researchers have observed that geographic patterns of lending are consistent with this mechanism." (ibid., page 9)

An awareness of the line between relational links and a definitive demonstration showing "why these associations exist"- s pervasive in this literature. Even the powerful indictment by Wyly et al. (2006) of subprime lending as race/class exploitation notes the need for "extreme caution on the crucial question of racial and ethnic discrimination" (page 114). The importance of this distinction is highlighted by what Wyly and Holloway (2002) have termed the "disappearance of race in mortgage lending." One problem is non-compliance by nondepository lenders with Home Mortgage Disclosure Act (HMDA) requirements that racial/ethnic data be reported for borrowers. A further problem is that only fragmentary data about predatory lending, including subprime mortgages, is publicly available. And no public data are systematically collected and reported for foreclosures; only proprietary data are available. The implications are profound:

Econometric analyses indicate that nondisclosure is driven primarily by lending-industry practices, with the strongest disparate impacts in African-American suburbs. Predatory lending is producing ambivalent spaces of racial-ethnic and gender invisibility, requiring new strategies in the reinvestment movement." (Wyly et al. 2007, page 2139) 


\section{HOW ECONOMISTS HAVE EXPLAINED RACIAL DIFFERENTIALS IN MORTGAGE MARKETS}

The recognition by Been et al. (2009) that they have not identified a "mechanism" accounting for "the distinct role of targeting in racial disparities in mortgage outcomes" is telling; it recognizes these authors' understanding that their analysis does not meet the standard for proving that subprime lending involves unfair treatment on the basis of borrower race. This requires further examination.

Until the launching of subprime lending in the 1990s, unfair treatment in mortgage markets involved two practices. The first was redlining: the systematic denial of home mortgages to urban areas with high proportions of minority residents, controlling for these areas' economic characteristics. The second was racial discrimination, the practice of systematically denying credit to otherwise creditworthy customers solely on the basis of their race or gender. When subprime lending was added to this picture, both definitions had to be expanded: redlining now involved channeling more subprime loans to high-minority areas than are justified by these areas' economic characteristics; and discrimination, systematically approving subprime credit contracts for customers who should qualify for prime credit contracts.

\section{Ambiguous Empirical Evidence}

Since the passage of HMDA in 1975, banks have been required to report annually on the location of their home-mortgage loans. This has resulted in a huge empirical literature exploring whether these data demonstrate the existence of unfair decision-making by banks. ${ }^{4}$ From 1975 to 1989 , lenders reported only home-mortgage loans made (in several categories) by census tract. This permitted investigators to construct models explaining why loan levels differed across urban space. For example, one representative study (Bradbury, Case, and Dunham 1989) showed that "race matters" in mortgage decisions in Boston. These studies were countered by others pointing out the possible significance of factors that were left out. For example, Holmes

\footnotetext{
${ }^{4}$ For a detailed discussion of this empirical literature, see Dymski (2006b).
} 
and Horvitz (1994) argued that redlining studies didn't take into account the spatial distribution of loan demand or greater lending risk in "redlined" areas.

HMDA reporting requirements tightened in 1990: from then on, lenders had to report data at the application level, including gender and race/ethnicity, for every home-mortgage loan application. Empirical studies now focused on whether the probability of being approved for a home loan was affected by applicant race and by the racial composition of the area surrounding the home which the applicant was seeking. Among these, a study of Boston stood out. Researchers at the Federal Reserve Bank of Boston were given complete access by Boston's bank lenders to their case-files on 1990 home-mortgage applicants; the resulting study (Munnell et al. 1992) thus thoroughly accounted for how banks themselves calculated applicant creditworthiness. This study found that African American applicants had a $40 \%$ greater probability of loan denial than other borrowers, all else equal.

This seemingly definitive result of unfair treatment received numerous challenges. Among the criticisms made, two are especially relevant here. Bostic (1996) argues that race effects may work through other variables. So he "interacts" the borrower-race variable with other creditworthiness-linked variables. In a probit equation (for the 1990 Boston data) containing both these "interacted" variables and applicant race per se, the former are statistically significant, but the latter are not. Bostic observes that the former result does not establish racial discrimination. Courchane and Golan (1999), by contrast, made a conceptual critique: the probit equation used implicitly assumes that banks evaluate every borrower independently, on his or her own merits. But banks operate differently: they establish benchmark criteria for creditworthiness, and evaluate applicants against those benchmarks. So racial discrimination would exist only if banks used a stricter benchmark for minority applicants than for whites. Ross and Yinger (1999) did a complete review of the Boston study and the criticisms thereof, including a re-estimation of the equations. These authors came to two conclusions, which have been seconded by virtually the entire literature on home-mortgage lending: first, the large racial gap in loan denial cannot be attributed to misspecification or data problems; and second, no study-including the 1990 Boston Federal Reserve study-has demonstrated either the presence or absence of disparate treatment discrimination in loan approval on the basis of race or ethnicity. And as noted above, studies of subprime lending have not succeeded in overturning these conclusions. 


\section{Conceptual Models of Discrimination: A Search for Racial Perpetrators?}

How could the many empirical studies of race and home mortgages have reached only the timid conclusion that race effects exist, but have no clear implication regarding lenders' malfeasance? We can explain this hesitant finding by clarifying what economists are looking for. For economists, an unjust outcome in a lending process can be built from two elements: first, the lender's intention of engaging in unfair treatment; second, a definition of fair versus unfair treatment in the credit market. Intent to harm and unfair treatment are separable.

Intent to harm-the existence of a racial perpetrator who disadvantages a class of agentsis necessary but not sufficient, as Becker's 1971 study of racial discrimination in the labor market showed. An owner (or lender) who will not make fair contract offers to agents she considers odious, is only opening herself to disadvantage in the market. For owners (lenders) who are not biased will snap up the good hires (good risks), with lower search costs. Because it is irrational, it is also inefficient; so market forces will cause discrimination to disappear, and laws such as the CRA impose unnecessary social costs. Becker's simple case falls apart readily when any of a number of simplifying assumptions-perfect competition, the absence of spillover effects, etc.-are absent.

Note that unjust treatment could result without intent to harm; for example, due to a lender's relative incompetence in evaluating minorities or women. If harm results, economists would expect competent lenders to take market share from the incompetent. Between incompetence and predatory behavior is an intermediate situation, in which a lender uses race or gender in selecting applicants because that lender wrongly believes that these characteristics are linked to creditworthiness; so there is prejudice, not malice. In the case of unfounded prejudice, as well, economists would expect unprejudiced lenders to outperform prejudiced lenders.

Next, what constitutes unjust treatment? Answering this requires differentiating between market processes and market outcomes. Agents in the same product class can expect to be treated the same way-to fill out the same forms, provide the same information, and so on. But they cannot expect the same outcomes. Note that the definitions of redlining and discrimination set out above do permit lenders to treat borrowers and areas with economically different characteristics differently. "Treat" here refers primarily to market outcomes, but may extend to elements of market process. When loan applicants have different incomes and job-loss risk levels, and these are linked to default risk, economists would expect these applicants to face different terms and conditions, and/or probabilities of denial. If applicants are identified in a 
(uniform) screening process as likely to be in a higher risk-class, their differential "treatment" might encompass stricter screening. Regarding racial discrimination per se, the question at every step is whether applicants are separated into risk classes solely because of race. The correlation of risk-class and race makes the distinction a fine one-recall Bostic's unwillingness to interpret racially-differentiated parameters in a creditworthiness assessment as evidence of discrimination.

If the market context approaches a perfect-competition ideal, with complete information, zero transaction costs, and low entry costs, then we can readily imagine that any emergent unfairness - treatment unjustified by fundamentals related to creditworthiness-will be resolved by market forces. Whether a given loan applicant should be classified as "high-risk" or "lowrisk", for example, can be accurately determined in a complete-information world, since every lender will have both instantaneous access to her background information and the ability to make a better instantaneous offer if one is warranted. Classificatory inefficiencies represent profit-making opportunities.

But in the real world, the market context deviates systematically from the idealinformation is both incomplete and asymmetric; information can be obtained and transactions completed only at a price, and entry into an industry carries significant fixed costs. These deviations from the ideal then hamper or eliminate this self-correcting capacity. In this case, fair treatment will not invariably emerge from market interactions. Economists have focused on the implications of transaction costs and asymmetric information. They have largely ignored market entry (or more broadly, the competitive structure of banking markets); we will expand this point in section 6 below.

Suppose first that it is costly to make a complete assessment of any one applicant's creditworthiness, and that several factors that are relevant for determining creditworthiness are correlated with applicant race. Then individual or area race can be used rationally to help determine who should get credit, on what terms. Indeed, discrimination becomes rational: lenders can use race or characteristics correlated with race to make valid predictions about borrowers' ability to repay debt and their probability of default. ${ }^{5}$ In such a situation a lender may treat two individuals of different races with the same financially-relevant information differently, without being a racial perpetrator. Hunter and Walker (1996) have even suggested

\footnotetext{
${ }^{5}$ Arrow (1972) first suggested this idea in an essay on labor market discrimination. Stiglitz and Weiss (1981) points out that banks might rationally redline minority neighborhoods if race is a signal of higher risk.
} 
that lenders may more accurately assess same-race individual applicants due to "cultural affinity." That is, cross-ethnic informational barriers can at least partly explain why white lenders more frequently deny (or impose stricter conditions on) applications from minorities.

This outcome is not "fair" to minority applicants: from these applicants' viewpoint, the lender is substituting population averages for their own data. However, if agent rationality is prioritized, then it would not be "fair" to lenders to mandate that they engage in costly application-level analysis that leaves them with sub-optimal profits. So profit maximization trumps accuracy in assessment. The fact that this differential population experience may have arisen due to racially-biased evaluations and racial perpetrators is not any one lender's problem to take on.

If asymmetric information is present, the same point is reached. Asymmetric information enters in when applicants' ability to repay a loan depends at least in part on unobservable competence, and/or on choices (for example, effort level) that applicants will make only after credit has been granted. In these two cases-respectively, adverse selection and moral hazardlenders are at an informational advantage that both affects default risk and that has no costless remedy. ${ }^{6}$ Adverse selection is especially important in choosing among applicants. Lenders will seek out signals of applicants' capacity to perform and repay (high to low), so they separate those who should be funded from those who should not. Signals of applicant capacity are most reliable when they are costly to emit and more capable applicants can emit them at lower cost (Spence 1974). Race itself fails this test; but Calomiris, Kahn, and Longhofer (1994) have suggested that applicant or neighborhood race may represent an efficient screening tool. This conclusion would follow if it is costly for lenders to interpret signals of creditworthiness that are tightly linked to applicant race/ethnicity: in this case, rather than augmenting their application process to encompass these signals, lenders could simply classify applicants by race.

The solution would seem to be reducing information costs and permitting more competition to serve the aggrieved applicants. Technological progress in banking, on one hand, and opening the way to more competition in banking, on the other, should gradually reduce these barriers to fairness. If asymmetric information is present, in turn, lenders must invest in applicant-assessment technologies, and create rules for classifying applicants into groups. Again, technological progress and more competition in banking will reduce barriers to credit-

\footnotetext{
${ }^{6}$ In particular, raising the lending rate will most likely reduce the proportion of competent applicants in the applicant pool. See Stiglitz (1987).
} 
market access. Until these barriers are sufficiently low, lenders can rationally use race and ethnicity to screen borrowers. Good business sense, not racial perpetrator animus, lies behind this.

So discrimination and redlining exist because high information costs lead profitmaximizing banks to use race as one form of informational shorthand. Minorities' true creditworthiness levels are not seen because information is crude. In their real circumstances, however, the riskiness of borrowers differs for numerous reasons no matter their race or ethnicity. Thus applicants will be more accurately served if they can be sorted more finely into different sorts of contracts. This is precisely what the emergence of subprime and alt-A loans should represent: loan contracts priced differently from "plain vanilla" loans because they are designed for riskier customers. The stiffer penalties and higher rates that subprime customers pay are simply the market's response to their circumstances.

In this perspective, subprime lending and securitization are innovations that will improve credit allocation and expand access to capital. For example, Fender and Mitchell (2005, page 2) argue that structured finance overcomes "adverse selection and segmentation." while Partnoy and Skeel (2007) discuss how "financial engineering [can be used] to complete markets". They write: "Because synthetic CDOs...essentially create new instruments, instead of using assets already on bank balance sheets...complete markets by providing new financial instruments at lower prices." (11-12) For borrowers, more complete markets provide a more contractual choices for borrowers and better pricing of risk (Barth et al 2008). Austan Goolsbee (2007), while principal economic advisor to Barack Obama during the 2008 campaign, articulated precisely this view of the potentially positive social and economic impacts of subprime lending in an op-ed article in the New York Times. ${ }^{7}$

This entire line of argument suggests that banks may be justified in using race and ethnicity as means of sorting borrowers into groups, and are certainly justified in using defaultrisk-related variables correlated with race and ethnicity. The existence of racial perpetrators is relatively unimportant for whether unfair treatment exists in the credit market; and it is difficult to establish the existence of unfair treatment due to applicant race or ethnicity when race and ethnicity are closely correlated to default-risk factors. Those who are subject to such rational discrimination can ask why they should be singled out in credit markets for risks that originate

\footnotetext{
${ }^{7}$ Goolsbee's arguments are largely based on Gerardi, Rosen, and Willen (2007). A closely similar argument was made by the Shadow Financial Regulatory Committee (2001).
} 
in labor markets or elsewhere; banks can rejoin that these spillovers are not their responsibility, do affect creditworthiness, and can legitimately be used in loan decisions.

The reasons for economists' failure to identify racial inequality or exploitation as one of the causes the subprime crisis are now clear. They largely rule out predatory racial behavior; and view the recurrence of systematic vulnerability in multiple markets for any subgroups of loan applicants as outside the boundaries of "economic" analysis. And since other social scientists permit economists' definition to govern discussions about discrimination, there is little left to say. Once variables correlated both with race and creditworthiness are ruled out of bounds, little if any empirical evidence can meet the double discrimination threshold of intent to harm and unfair treatment.

\section{A MESO ANALYSIS OF THE EMERGENCE OF SUBPRIME LENDING AND ITS CONSEQUENCES}

Meso analysis "concerns itself with the structures that mediate between individuals and the economy considered as a whole" (Elson 1994, page 33). The term did not originate within feminist economics, but has been used widely in this field. As Elson points out, in the neoclassical economic vision, any institutions operating in markets are understood as "the outcome of voluntary contracts" (page 34); the state is "absent from the micro level" (page 35). Gender is conceptualized at the micro level, and excluded from the meso and macro levels, since "mediating structures ... cannot be identified as 'male' or 'female'." (page 36) But then, "If these institutions and instruments operate in ways that are detrimental to women, then this is fundamentally due to the characteristics of individuals at the micro-level, and in particular to prejudice against women." (page 36)

Elson highlights the importance of undertaking gender analysis at the meso level, so as "to analyze how male bias is constituted at the meso- and macro-levels, at the level of mediating institutions and instruments" (page 39). Elson demonstrated this approach in a 1999 paper showing how labor markets are gendered institutions, in which "discrimination against women may persist because ... it is profitable.” (Elson 1999, page 611).

These insights are reprised at length here because this is precisely the level of analysis that is missing in most writing on racial inequality in credit markets. The parallels with Elson's 
work on the labor market appear to be fairly exact. But her conclusion about profitability and discrimination brings us to a paradox that is at the heart of understanding the links between racial inequality and the subprime-lending crisis: if minority neighborhoods and applicants were so systematically unworthy of housing credit at the same rates as other areas and applicants, how did they become so systematically included with the advent of the subprime loan?

One obvious possibility is that the housing-price bubble made subprime loans a necessity throughout the housing market. But as we show below, the sequence was the opposite; subprime lending emerged well before the housing-price bubble. Another obvious explanation is that lenders became more tolerant of risk. But as we shall see, one key to the take-off of subprime lending was precisely a method for shifting risks off lenders. ${ }^{8}$

This said, it is helpful to consider what a meso analysis must supply by thinking in terms of the demand for and supply of subprime loans. A source of demand would arise from loan applicants who lack access to credit; have untapped resources (collateral) on which to draw in event of a default; have no other recourse for borrowing on the scale needed; and have a desperate need to borrow. On the supply side, we need to establish that subprime lending is, first of all, a vehicle for increasing expected profit on a scale large enough to warrant the fixed-cost investment needed to initiate this lending. This means, in this case, identifying how banks accommodated these loans' excessive riskiness and built up this market's potential volume, and also what events pushed them onto this competitive playing field.

\section{From Financial Exclusion to Exploitative Inclusion via Subprime Lending}

Before the neoliberal era, the U.S. banking system consisted of segmented markets in which price and geographic-market competition was disallowed. Commercial banks rarely made consumer loans. Thrifts captured households' savings deposits, and used them to support mortgage lending for housing purchase and rehabilitation, often channeling funds from the Federal Housing Administration (FHA).

This system did not deliver transaction, deposit, and credit services uniformly: banks ignored and underserved lower-income and minority areas. The FHA used underwriting criteria

\footnotetext{
${ }^{8}$ Similarly, the three "narratives" that Elliott and Baily (2009) argue have been constructed to assign blame for the 2007-09 financial crisis - government housing and housing-finance policies, reckless and greedy behavior by Wall Street, and "a wide range of people and institutions, ... including many outside the United States" (page 4), do not account for this paradox. US housing policy did not change between 1995 and 2008. Invoking Wall Street's greediness does not explain how this greediness was mobilized to profit from subprime lending. And these authors' third explanation actually constitutes, in effect, a call for a meso-analysis.
} 
that explicitly discriminated against minority areas until the 1960s (Hernandez 2009). Indeed, once the pressure from the Civil Rights movement opened the FHA program to minority areas, the character of FHA loan-making was transformed. Most home purchases (especially for 'move-up' homes) were financed with conventional loans; FHA loans were increasingly used to finance homes for first-time buyers and for buyers in minority areas. For while FHA loans required lower down-payments, more guarantees regarding borrower income, and stricter home inspections, they were (and are) underwritten by the Federal government and thus are essentially riskless from a lender's perspective. In effect, even after racist language was stricken from FHA lending guidelines, housing finance remained fraught with inequalities defined along racial lines. ${ }^{9}$

And this racial divide did not pertain only to lending. Banks maintained many fewer branches in minority neighborhoods than elsewhere (Dymski and Veitch 1996). Households in these areas often used high-cost "fringe bank" (Caskey 1996) alternatives. Lending and service imbalances so disadvantaged inner-city areas that a national community reinvestment movement succeeded in pressuring Congress to pass the HMDA and the CRA in 1975 and 1977, respectively.

High interest rates and recession in the late 1970s and early 1980s led banks to lose high-balance deposit customers to non-bank intermediaries, and blue-chip-business borrowers to the commercial-credit and bond markets. Money-center banks had large loan losses due to the Latin American debt crisis, and thrifts experienced negative cash flows and then insolvency problems, compromising the flow of mortgage credit. State and federal deregulation acts in the early 1980s and changes in federal regulatory capacity and philosophy permitted surviving banks and thrifts to launch a general merger wave and to engage in a much wider range of activities. With money-center banks on the sidelines, a new set of ambitious large bankssuperregionals such as NationsBank and BancOne-appeared. These institutions began to use mergers to increase their market areas; they were especially interested in identifying and capturing prosperous, asset-rich customers to whom multiple financial products (credit cards, interest-plus deposit accounts, and so on) could be marketed. This involved not only

\footnotetext{
${ }^{9}$ Aldana and Dymski (2004) show that in the county of Los Angeles, in the 1990s, FHA loans were used disproportionately to finance housing for minority households in "inner-core" areas, and for white households in suburban areas. These authors' probit analyses of loan approval and denial confirmed that African Americans, in particular, were at a significant statistical disadvantage in accessing conventional home-purchase loans anywhere in Los Angeles, and in applying for FHA loans in suburban areas.
} 
acquisitions, but also heavy investments in centralized data-bases and data-processing facilities, which in turn shifted the informational basis of loan-making from personal knowledge to standardized assessments based on households asset, debt, and income levels. Customers with low balances were increasingly forced to pay fees to maintain accounts; those with higher balances-for whose assets banks were competing with non-bank intermediaries-often enjoyed zero fees.

Meanwhile, the home-mortgage market was reshaped. Thrifts' savings were set aside as the predominant source of finance for home purchase loans. Instead, home finance was provided directly through securities markets. To offset investors' concerns in the tumultuous 1980s, government-sponsored enterprises in the housing-finance arena (especially the Federal National Mortgage Association and the Federal Home Loan Mortgage Corporation-respectively, Fannie Mae and Freddie Mac) nurtured a vast expansion in the mortgage-backed securities (MBS) market. Fannie and Freddie underwrote "plain vanilla" mortgages that satisfied conservative loan-income and down payment criteria (30 percent and 20 percent, respectively), bundled them into MBS, and sold them into the markets. Several private firms provided these services for “jumbo" loans exceeding FNMA's sales-price maximum. Taking advantage of these new arrangements, non-bank mortgage companies and commercial banks rushed into the vacuum left by thrifts rapidly-eroding share of mortgage finance. Note that mortgage companies' aggressive entry into the market, combined with thrifts' sudden shrinkage, provided the "push" for banks to get into the MBS market.

Facilitating this market shift was the explosive growth of markets for loan securitization. More and more categories and risk classifications of loans could be offloaded onto non-bank portfolios after being originated by bank or non-bank lenders. The MBS market became the biggest securities market in the world by the end of the 1980s, a status facilitated by the US's chronic trade-account deficit (which resulted in steady foreign demand for dollar-denominated assets).

Banks' strategic shifts in the 1980s had several implications for banking in minority and lower-income areas. The bank branches that remained in these areas functioned less as mechanisms for pooling savings and more as vehicles for generating fee-based revenues (Dymski and Veitch 1996). Advances in information and securitization technology, which fueled the growth of upscale retail banking, led in the 1990s to the transformation of "fringe banking" (Barr 2004). The closure of bank branches in minority areas, and the influx of ethnic- 
minority immigrants into these neighborhoods, meant large clusters of underserved households. Banks had low shares of these markets-only three percent of the remittance market as of 2000 (Orozco 2004). And these markets-initially, for debit cards, remittances, money-orders-were growing explosively. Banks' lack of market share in these rapidly-growing "fringe banking" markets, in effect, provided a further competitive "push": banks had to compete with interest in these expanding customer markets pushed them into competing with non-banks to provide money and credit services to these customers-this was another "push."

Banks began to compete for "fringe banking" business, directly and indirectly. As check-cashing stores began extending credit to their customers, especially via payday and taxrefund anticipation loans, they moved from a cash to a funding basis. They made upstream connections with banks, sometimes through parent corporations, routinizing their access to funds. So check-cashing stores were increasingly operated as franchises, and-as banks bought their parent corporations-were increasingly subsidiaries of large banks. By the mid-1990s, community activists classified these loans as "predatory:" their high interest rates, high fees, onerous non-payment penalties, and short maturities made them both substantially more expensive than primary-market loans, and also far more likely to end in default (or punitive rollover). Borrowers for predatory instruments often were desperate for credit, as they were more likely to be in households with members who were unemployed, imprisoned, and/or without adequate medical insurance.

By the 1990s, subprime mortgage loans already emerged as the most well-known form of predatory lending. Initially, subprime loans were marketed in minority neighborhoods, whose residents had often been denied access to mortgage finance. In some cases, these loans were sold as second mortgages to cash-poor, house-rich households. In other cases, minority loan applicants who previously would have been denied a home-purchase loan were provided with one-via a loan with higher carrying costs, larger fees, and more risk of loss than a conventional mortgage loan. In the US, subprime loans grew by 900\% between 1993 and 1999 (HUD 2000). They were made disproportionately in minority neighborhoods. A nationwide study of 2000 HMDA data by Bradford (2002) found that African Americans were, on average, twice as likely as whites to receive subprime loans, and Latinos were nearly twice as likely.

Facilitating the growth of predatory and subprime lending was the growth of outlets for placing this high-risk credit. One key was the creation of the structured investment vehicle (SIV). This instrument, invented in 1988 for Citibank, permitted banks to fund higher-yield 
paper using commercial paper, off-balance sheet (Mollenkamp et al., 2007). The demand for subprime securities was further expanded by the Gramm-Leach-Bliley Act of 1998, which removed prohibitions against combinations of banks, securities companies, and insurers, and the Commodity Futures Modernization Act (CFMA) of 2000, which clarified that over-the-counter derivatives transactions would be regulated only under weak federal "safety and soundness" guidelines. Further, the Federal Reserve was skeptical about efforts to regulate predatory lending; it took more than seven years to publish regulations implementing the 1994 Homeownership Equity Protection Act (Greenspan, 2010, pages 13-14). These legislative changes permitted large banks to undertake new activities, and facilitated the growth of new investment vehicles, such as hedge and private-equity funds. The high risks associated with predatory lending, and in particular the rapidly growing subprime loans, was handled in two ways. First, securities bundlers and buyers relied on credit-rating agencies' certification of the security's default-risk level. The sterling reputation of Wall Street credit-rating agencies made this a nearly automatic prospect. Second, risk was also insured via derivatives green lighted by the CFMA; most infamous were AIG's use of credit default swaps to "insure" the paper written by its megabank customers (Sorkin 2009).

So borrowers in predatory and subprime loan markets participated indirectly in all the machinations of Wall Street's cash-flow-bundling and risk-redistribution apparatus. Financial exploitation that in the past would have involved localized oppression was now conducted via the routinized extraction of excess interest and fees by megabanks and mutual funds. Of course, the institutional plumbing required for securitizing predatory credit was not created for the sole purpose of extracting fees and wealth from lower-income neighborhoods and people of color. These institutional mechanisms were used to offload many other kinds of debt, including creditcard debt, automobile loans, student loans, and manufactured housing loans. By the end 1990s, nearly $\$ 1$ trillion of asset-backed securities were outstanding (FCIC 2011, page 45). So originate-to-distribute lending took off.

When US housing prices began rising to unprecedented price-to-income ratios in the early 2000s in some markets, the mechanisms for rapidly increasing the volume of high-risk loans were in place. What qualified as "high risk" was reframed. In making subprime loans to existing and prospective home-owners in minority areas, lenders offset the insecurity of borrowers' incomes with the security offered by a home whose value far exceeded the loan on that home. As housing prices boomed in many areas, "high risk" came to mean loans for which 
unsustainable loan-income levels were made in anticipation of continued housing-price appreciation. At its peak in 2006, subprime lending accounted for $23.5 \%$ of sales in the US housing market (FCIC 2011, page 70), becoming a "new normal." At the same time, section 3 above has already emphasized that households in minority areas were disproportionately targeted for subprime loans, even when they could have qualified for prime loans. The stage was then set for a global financial crisis, the details of which we pass over here.

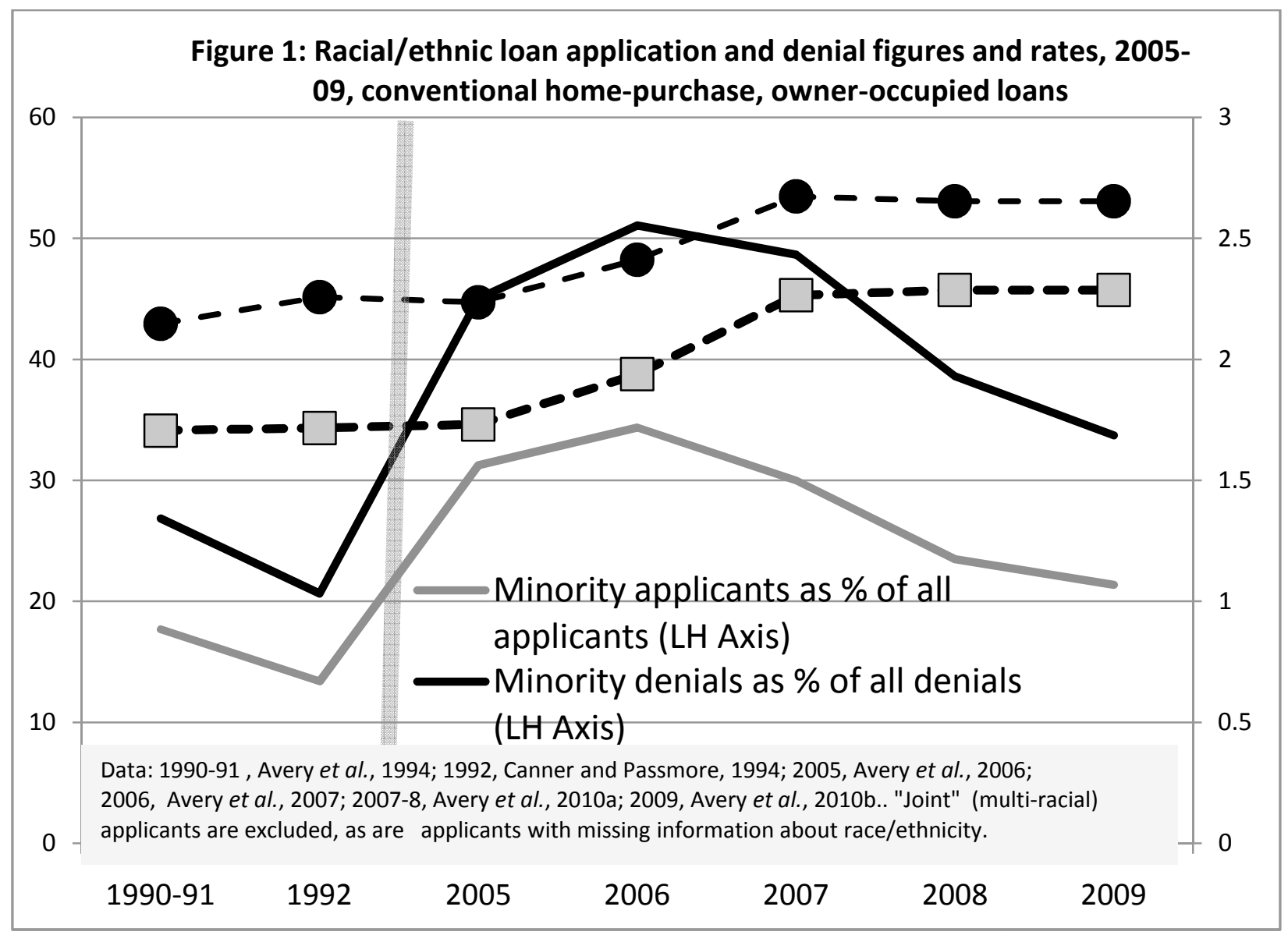

\section{Recentering the Subprime Crisis}

The explicit introduction of a meso level of analysis permits us to include loan-applicant households with gender and racial-ethnic characteristics directly into the analytical framework. This lets us understand these unfolding events not just as a crisis of market mechanisms, and not just as a generalized crisis experienced by all homeowners or market participants, but as a crisis that unfolded along racialized lines. This helps us resolve the apparent paradox of how borrower communities previously excluded from access to housing finance were provided with a tailormade credit instrument: it arose via the step-by-step co-evolution of banking strategies and client communities, shaped by and reinforcing patterns of racial/ethnic inequality. 
That there was no simple shift from exclusion to inclusion in housing credit is shown by Figure 1, which displays data for conventional home-purchase loan applications for years 199092 and 2005-09. ${ }^{10}$ In this figure, the ratio of the African-American denial rate to the white denial rate was over 2.0 in the early 1990s, and actually rose above 2.5 in the mid-2000s. Denial-rate ratio data comparing Hispanic and white applicants shows an identical pattern from a slightly lower base (1.7). One notable difference between the early-1990s and mid-2000s data is the growing share of minorities among applicants. Figure 1 also illustrates that in 2005-7, minorities accounted for less than a third of all conventional home-purchase applications, but about half of all denials.

The emergence of subprime lending did not involve lenders becoming more risk-tolerant or risk-loving. For one thing, as noted above, lenders had since the 1960s been making FHAunderwritten home loans in disproportionate numbers in minority and lower-income areas. For another, subprime lending grew only when means were found to shift risk off banks' balance sheets without relying on government underwriting. In the first phase of subprime lending, subprime mortgage loans were often well-collateralized-they were frequently second mortgages that turned home equity into cash. In the second (post 2001) phase of subprime lending, thirdparty underwriters willing to ride the housing bubble emerged. But even so, rejection rates for subprime loans were high. Hernandez (2009) shows this in a case study of Sacramento; and in a nationwide analysis of the densities of subprime lending, Wyly et al. (2008) also find high subprime rejection rates; as these authors put it, "unequal subprime segmentation goes hand in hand with rejection and exclusion." (page 18)

Indeed, for many borrowers, subprime loans were not means to acquire homes, but instead generated cash-flow for households trying to make ends meet. We should reemphasize here the finding by Schloemer et al. (2006) that distress refinancing-not new-home acquisitionprovided the motivation for more than half the subprime loans made in the 2000s; and as noted, in communities where housing prices were not appreciating, foreclosures became an epidemic well before subprime lending collapsed in September 2007. In sum, subprime lending was never the rosy alternative path to homeownership that analysts such as Goolsbee (2007) made it out to

\footnotetext{
${ }^{10}$ HMDA data are used. Figure 1 presents an interrupted time-series because HMDA data are not available as continuous time-series. Raw HMDA data require "scrubbing" before they can be reliably reported, and different analysts use different conventions when scrubbing. Figure 1 uses exclusively data reported in Federal Reserve articles co-authored by Glenn Canner and/or Robert Avery. These two economists have co-authored most Federal Reserve Bulletin articles summarizing HMDA data.
} 
be; motivations and consequences were embedded in the complex, evolving, raciallydifferentiated circumstances of a post-Fordist society with stagnant incomes and housing-price appreciation.

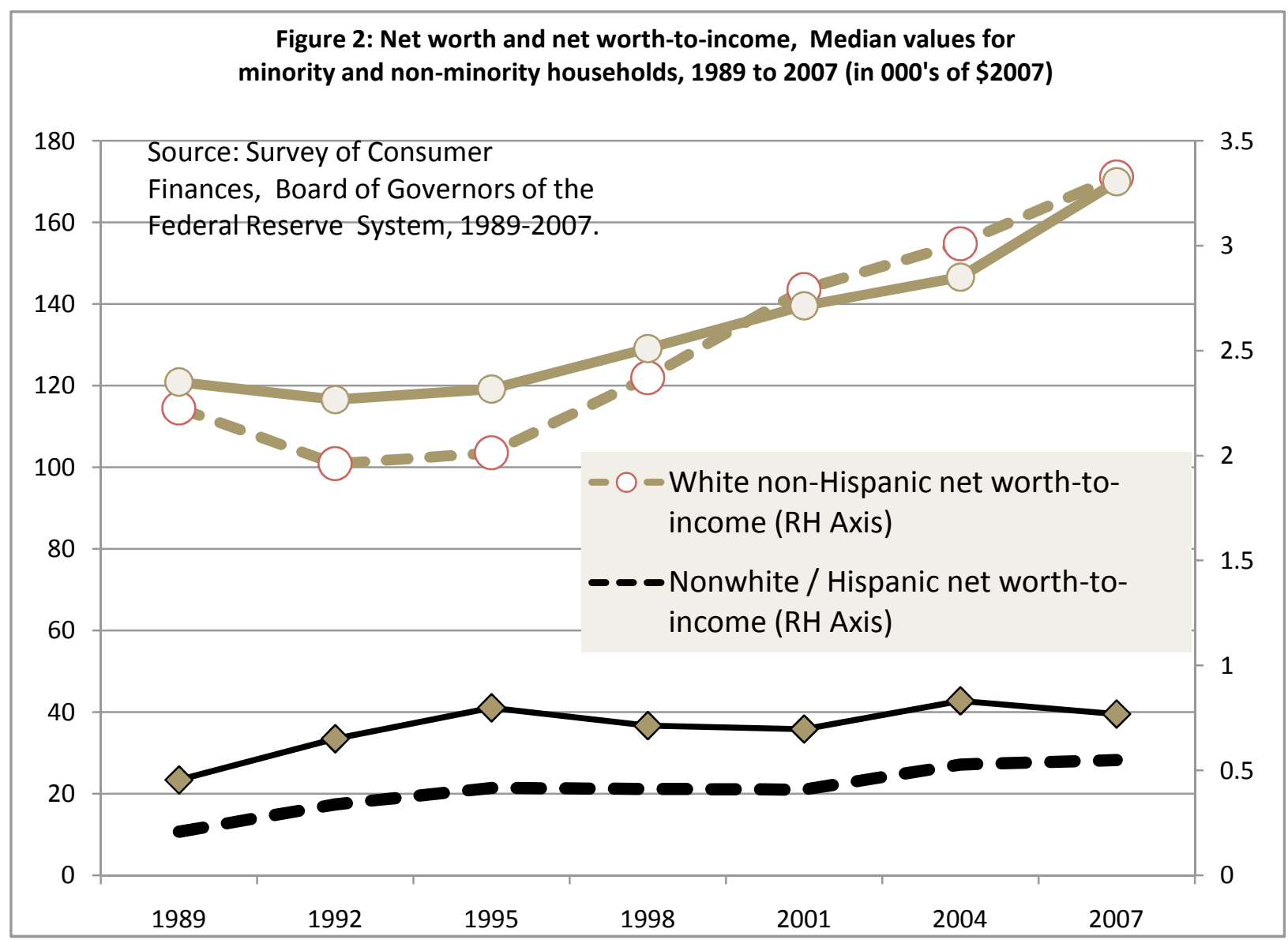

Figure 2 uses median data from the Survey of Consumer Finances to illustrate the weak or negligible impact of the subprime lending period on minority wealth accumulation. It shows that while the levels of net worth and net worth-to-income levels for white (non-Hispanic) households climbed steadily from 1995 to 2007, those for minority households remained essentially flat. No cumulative aggregate wealth "catch-up" effect is evident, even before the housing-market crash took full effect. 


\section{SUBPRIME LENDING AND STRUCTURES OF MARKET POWER}

The meso analysis in section 5 makes visible the interplay between socially excluded fragments of society and the market institutions they depend on for credit and financial services. There remains a further paradox to resolve. The spread of subprime lending from isolated urban pockets to large portions of the US housing market involves an asset boom in which many players wanted to participate. How is it, then, that even in the boom period, with mortgage brokers being minted by the hundred in some markets, the disproportionate disadvantage of minority borrowers remained in place? To state this differently, why weren't more minorities shifted from higher-rate, higher fee, shorter-term mortgage packages to lower-rate, lower-fee, longer-term packages?

The answer has to do with the complex intersections of subprime lending with structures of social and market power. The impermeability of subprime lending is linked to Elson's point - it was profitable. But to see how and why involves an exploration of the archaeology of racial power, wherein the most recent layers rest on historical (not to mention multi-market) patterns of inequality bwhose effects will be magnified if they are not offset.

One set of agents can be said to have power over another, generally, when the former can restrict the choices, constrain the freedoms, and/or impose additional costs on, the latter. For economists, power arises in market settings when one side of the market contains either a sole buyer or seller-or a small self-coordinating and self-policing group of buyers or sellers (a cartel). In effect, on one side of the market are many buyers seeking a good, on the other is a seller who may increase her rents by establishing a price higher than she could maintain if she faced competition. It would seem that since those on the market's short side can set prices, they can readily extract rents, and thus economists should view market power as a near universal problem which, when unchecked, leads to inefficiencies. Instead, economists have largely set aside this concern. A key factor here was the acceptance of the Dixit and Stiglitz (1977) argument that if products are close substitutes, new entrants can enter if those already in the market set prices higher than would hold under perfect competition. If the credit market is viewed as a case of a lender facing multiple borrowers in several risk classes, then it is easy to visualize subprime lending as one of several close substitutes that could arise in response to market demand. 
But as emphasized in section 5, events unfolded very differently in the real world. Power instead unfolded in several phases. The points of entry for the subprime crisis go back to the migrations that brought African Americans, whites, and Latinos to US cities, as residents, owners, managers, and workers. Without entering into the details of these histories, we can recognize that processes of race-making were involved, processes of determining who had access to what resources and social positions, on what terms, and who did not. Markets were not neutral in these processes, but instead were tools for controlling access to scarce resources (Williams 1991, Darity 1989). In many cities, public/private partnerships took hold at the neighborhood level, creating a social infrastructure that assigned access to mortgage credit. These partnerships were centered on organized multi-scaled networks of real estate professionals intent on establishing and protecting market position by collaborating with public institutional rule-makers.

Race and ethnicity were two means of drawing lines in clear and decisive ways: and racial/ethnic divides had emerged in long histories of enslavement and dispossession that had specified whose rights to liberty, life, and property were more and less important. So this led to restrictive racial property covenants and to government policies of mortgage redlining that both drew on and reinforced popular prejudices. Subordinate groups were denied access to homeownership and forced into segregated spaces whose residents were systematically disadvantaged in terms of wealth ownership. Cooter (1994) has pointed out that in these processes, social groups operated as cartels to gain monopoly control over access to markets. Roithmayr (2007) has pointed out that housing-market monopolization of this kind, based on organized collectives that operate as 'racial cartels,' have been a common feature in many US cities' development. Roithmayr shows that the cartel's capacity for collective action enables lenders to use borrower race as a fundamental category for assigning market position (instead of a system in which, say, individuals earn their market position via competition).

After Civil Rights laws were passed in the 1960s and 1970s, explicit barriers to neighborhood entry on the basis of race were broken down. Attention shifted to the relative importance in generating differential racial outcomes of perceptual bias and animosity, on one hand, and structural inequality, on the other. Paralleling our earlier discussion, the former were viewed as clearly illegal; the latter were viewed as ambiguous (Dymski 2006). Paired-testing studies have consistently found that racial biases exist in all aspects of the housing and housing-finance market processes, even if they are not perceived as such by those engaged in these actions (Austen Turner et al. 2002). As noted, finding evidence of intent to harm in racially-differential outcomes is difficult at best, 
especially because participants in one market can explain the rationality of their decisions to exclude minority applicants on the basis of race-based inequalities in other markets.

This leaves us at many economists' point of departure regarding whether racial bias infects market processes. As Michael Omi put it: "the idea of 'race' and its persistence as a social category is only given meaning in a social order structured by forms of inequalityeconomic, political, and cultural- that are organized, to a significant degree, along racial lines" (Omi, 2001, page 254). In effect, race is both ever-present and absent in the play of market forces; some will see the effects of disparate racial treatment and outcomes everywhere; others will deny the importance of race in social and economic outcomes. The very fact that $50+\%$ of African Americans (versus 13-15\% of whites) seeking homes were provided with subprime loans means something-but something quite different than an alternative universe in which $100 \%$ of African Americans received subprime loans or, for that matter, no loans. What once required a cartel to coordinate has now, instead, been transported into market participants' perceptual framework.

\section{Power Relations in Subprime Lending}

A survey of 2005 and 2006 experience found that 55\% and 61\% those acquiring subprime mortgages, respectively, had credit scores high enough to obtain conventional loans (Brooks and Simon 2007). Restating the paradox posed above, why didn't market forces push loan-brokers to offer better terms and conditions, leading to either lower fees and interest-rate premia for subprime borrowers and/or to fewer (not more) borrowers in subprime categories? Another result in Brooks and Simon's investigation provided the answer: mortgage brokers selling these claims earned fees far higher than conventional mortgages would have netted. "Subprime" loan pushing resulted from incentive systems that paid brokers higher fees for subprime than for prime loans (Hudson 2010).

To see how this worked, note that the "originate and distribute" loan model creates a new role for banks within the architecture of lending and borrowing. The loan applicant interfaces with mortgage brokers who arrange loans with banks or with lending companies that have client relationships with banks; and the banks in turn bundle subprime loans, sometimes intermixed with other loans, into collateralized debt obligations (CDOs) that are typically placed with investors. The bank is no longer the lender, but instead is the enabler in this chain. It 
occupies the fulcrum position in a lending-servicing-investment complex. And at the hub of this complex are a small number of megabanks, whose reach extends to hedge, private-equity, and offshore funds, and who have privileged access to the underwriters and derivatives markets that permit risk-sharing or offloading.

According to the Center for Public Integrity (2011), the top 25 subprime lenders accounted for $\$ 987$ billion in new subprime loans in the 2005-07 period; just under half of this ( $\$ 470$ billion) was financed directly by one of the 14 largest bank holding companies as of December 2006. Based on a compendium of the contradictory existing data on subprime securitization and placement by the Office of the Comptroller of the Currency (2010), this (\$470 billion) figure represents one-third to one-sixth of all subprime lending in these years. So in effect, the many thousands of loan-brokers working with clients were funneled, directly or indirectly, into a relatively small number of financial channels. This funneling is one factor in the explosive growth of the very largest bank holding companies in these years, relative to the remainder of the banking population (Dymski 2010)-and the largest banks' near-monopoly position in derivatives-linked hedging markets and in overnight markets for liquidity.

This financing funnel helps explain why competition on the "front end" did not lead to reduced subprime participation on the "back end." In the placement step at the end of the process, where the funnel is tightest, higher-yield paper is preferred. Many of the investors demanding this paper have an organizational imperative to beat the market rate of return; and until September 2007, credit-default swaps were available to neutralize investors' downside risk. Banks earned higher fees for placing higher-yield paper; and they in turn paid more to mortgage companies for this paper. The brokers working for mortgage companies (and interacting directly with loan applicants), in turn, received fees that were higher, the more subprime features were incorporated into the loan contract struck. ${ }^{11}$ The fact that so many brokers were seeking to move subprime paper increased profits for the centralized lender/bundlers: these brokers, who often had "cultural affinity" with borrowers, circulated in historically redlined neighborhoods independently, reducing fixed-cost investments for lender/bundlers trying to reach loan applicants there.

\footnotetext{
${ }^{11}$ The authors have obtained several rate sheets used by large California mortgage companies in 2006. These clearly show the incentives at work. For example, raising the initial start rate by $0.5 \%$ would result in a $1 \%$ "rebate" to the loan broker - on a $\$ 300,000$ loan, this would work out to a bonus of $\$ 3,000$.
} 
An indication of how cumulative racial disadvantage translates into assertions of social power in the mortgage market is provided in Figures 3 and 4. These figures array data for 2005 homepurchase loans; 2005 is used as it represents the very peak of the subprime loan explosion. Figure 3 distributes home-purchase loans obtained by females in different racial/ethnic categories across census tracts, on the basis of these tracts' percentage of minority residents in the 2000 decennial census.

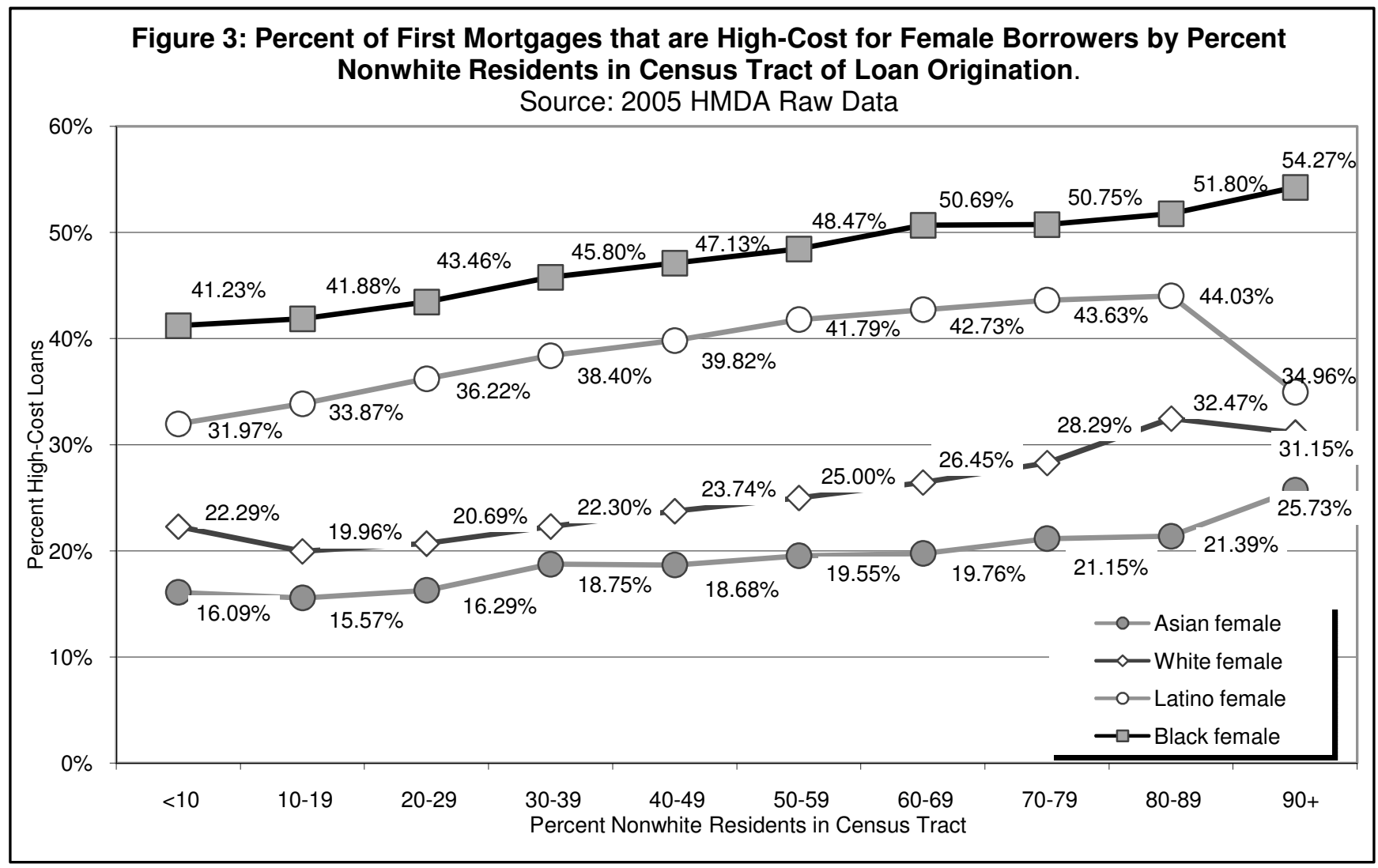

Figure 3 shows that in every racial/ethnic-minority residential concentration level, the ordering of borrowers in the subprime-loan percentage is the same: African Americans, followed by Latinos, followed by whites, followed by Asians. The likelihood that a female borrower in any category will have a subprime loan increases monotonically as the concentration of racial/ethnic minorities rises, almost without exception. However, this increase is not as dramatic as would be anticipated if the problem of subprime lending was simply a manifestation of residential racial segregation. To the contrary, the likelihood that an African American female borrower will not receive a subprime loan falls by only $24 \%$ if she shifts from the most heavily minority decile to the least. 


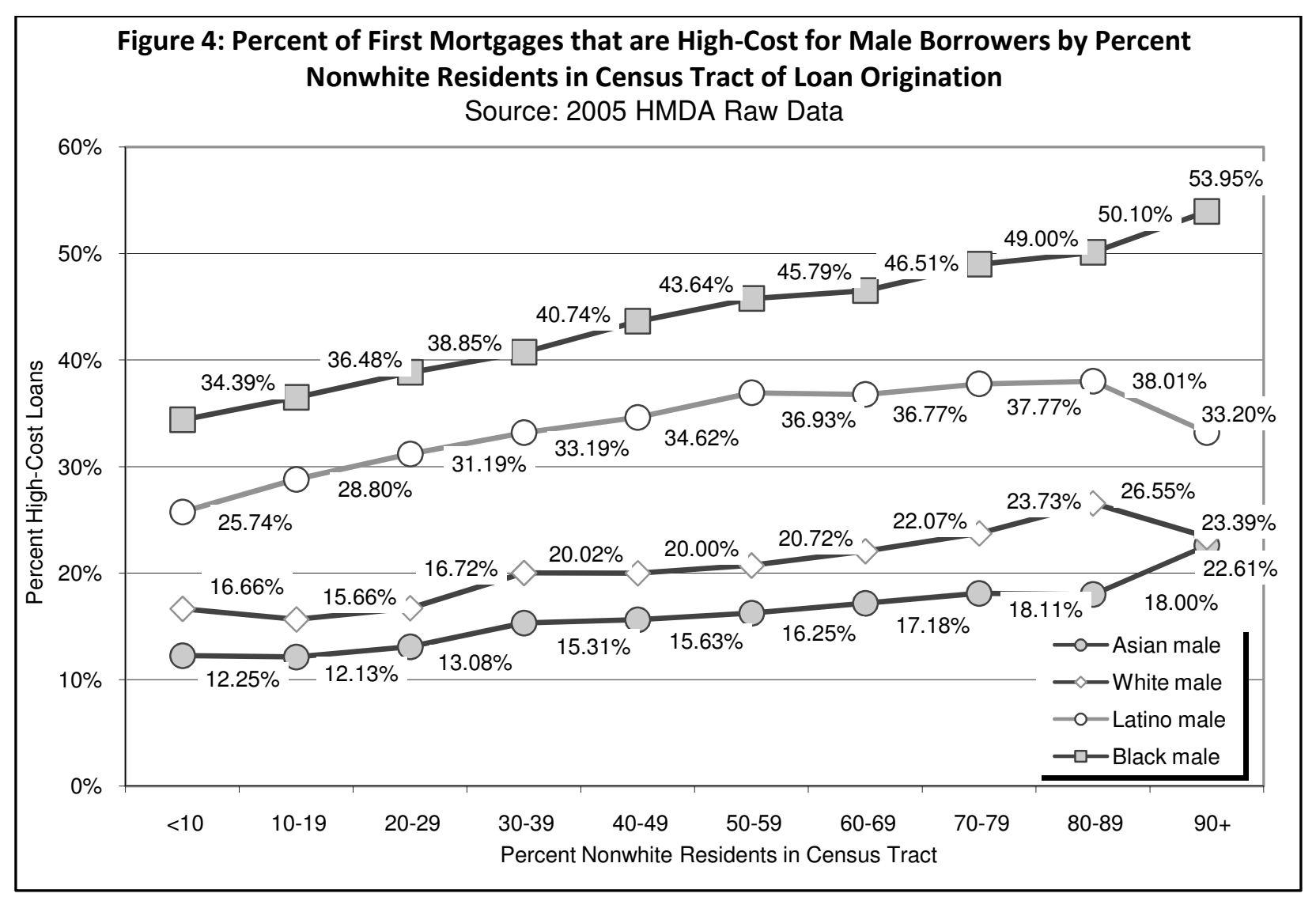

Figure 4 then presents the parallel data for male borrowers. There were almost twice as many male as female subprime borrowers in 2005: 1,093,419 high-cost loans were reported to HMDA in 2005 for female borrowers, and 1,845,068 loans for male borrowers. Figure 4 shows the same trend-lines as does Figure 3, with two significant differences: the percentage of subprime loans are lower at every decile and for every racial/ethnic category than for females; the differential in subprime-loan percentages between the lowest- and highest-minority residential deciles is less than for female borrowers, but still flatter than would be expected if spatial racial segmentation was the sole determinant of racial/ethnic disadvantage in home-loan markets. There is clear evidence here that women are systematically more disadvantaged than men across racial/ethnic lines and degrees of racial/ethnic segregation. And the evidence shown here suggests an additional dynamic is at work here beyond spatial racial segregation: if racial inequality in lending processes reduced to segregation, why is that in census tracts populated by less than $10 \%$ nonwhite residents, only $17 \%$ of white males get high-cost loan but over $40 \%$ of black women do? Further, why do only $23 \%$ of white men in census tracts with more than $80 \%$ nonwhites have high-cost loans, an amount 15 percentage points lower than for African American women in tracts with less than $10 \%$ nonwhite residents. It is clear that spatial 
segregation is not the only trigger for financial vulnerability; another trigger is applicant ethnicity. $^{12}$

In sum, monopoly-like control was exercised by a small number of megabanks, on behalf of return-seeking investors, through their control over the securitization choke-point in the mortgage process. Banks' shift from lender to enabler provided a new tool for reaching target populations that their upscale retail banking strategies had left behind, without taking on the risks that stemmed both from these populations' own fragile economic circumstances and from the onerous terms and conditions to which subprime loans exposed them.

\section{SUMMARY}

Many scholars in sociology, urban studies, and geography have characterized the subprime and foreclosure crises as rooted in US racial/ethnic segregation and inequality. But in most economists' explanations, race is largely irrelevant in these crises. This paper has attempted to explain why these two approaches to the subprime/foreclosure are so different. Race and ethnicity are missing in economists' accounts of these crises for much the same reasons that economists' explanations often overlook the impact of gender inequality: they attribute empirical evidence of widespread racial/ethnic differentials to factors beyond the realm of the "economic;" and they build explanations that appeal to unmeasurable differences in beliefs or motivations, or that highlight hitherto-unnoticed perverse incentives in market mechanisms.

And indeed, we have reviewed the compelling empirical evidence that links subprime lending and the subsequent foreclosure crisis with residential racial segregation, credit-market redlining, and discrimination. This evidence, while wide and deep, consists primarily of extensive correlations. Some social scientists trace these correlations to racial/ethnic segregation; but segregation alone does not show how market mechanisms generate exploitative outcomes, even in segregated space, and all such exploitation does not occur there. Economists, in their turn, have shown how these data can be used to assemble only incomplete cause-andeffect linkages. Economists' own tests for whether unfair treatment derives from racial factors

\footnotetext{
${ }^{12}$ It should be noted that applicants' average income levels are relatively flat by race/ethnicity across racial/ethnic residential concentration categories. That is, statistics shown in Figure 3 and 4 are not proxying for income differentials.
} 
in the credit market requires evidence of an explicit intent to harm. This has not been shown. And economists tend to view minorities' systematic disadvantage in spheres outside the credit market as factors that can legitimately explain high rates of loan denial and subprime lending for minorities. The spatial 'bunching' of subprime loans in high-minority neighborhoods, which constitutes ipso facto proof that market mechanisms malfunctioned in some social scientists' view, proves the opposite point for many economists.

What is missing in the social science view is any attention to market mechanisms; and economists on their side have drawn too tight a boundary for "the economic," focusing on market mechanisms per se to the exclusion of the households and community whose resources and outcomes these mechanisms affect. Because of these explanatory lacuna, neither approach can explain two defining aspects of the subprime crisis. First, why were borrowers that had previously been excluded from equal access to mortgage credit instead super-included in subprime lending? Second, why didn't the flood of mortgage brokers that accompanied the 2000s housing boom reduce the proportion of minority borrowers who were burdened with costly and ultimately unpayable mortgages?

We have answered these questions by constructing a meso analysis showing how subprime lending arose from a co-evolutionary process involving banking strategy, minority communities, and financial markets. The key for lenders, in particular, was the creation of new market-driven means of risk-shifting; indeed, the separation of loan-making from risk-bearing was fundamental in explaining why subprime loans exploded in volume even as housing prices soared.

The explanation for why competition did not reduce minorities' proportions of exploitative loans has historical roots in the racial segregation of US cities, which itself is the legacy of a race-making process by a racial cartel in urban housing markets. Actual cartel-like cooperation to purposely exclude minorities from equal access to housing, credit, or urban space was, by the time subprime lending came into being, buried deep in the past; its legacy to the present was a multi-dimensional, spatially-differentiated pattern of racial inequality affecting both households and the organization of urban space. In effect, subprime lending-and the subsequent foreclosure crisis-has had such a deep link to racial inequality not simply because of discrimination against minorities in credit markets, but because lenders' structural market power is systematically larger-and provides more opportunities to leverage short-term gains-in loanmaking that involves communities of color. The result of this systematic exercise of power will 
be a reversal of fortune in wealth accumulation in communities of color that will take decades to undo.

While our analysis has focused on racial and ethnic inequality, it has substantial implications for gender inequality. For one thing, as Figures 3 and 4 clearly demonstrate, women were more likely than men to receive subprime loans when buying homes-across racial/ethnic groups and independent of the degree of residential racial segregation. In the view of Fishbein and Woodall (2006), women were targeted for subprime lending. The wealthstripping implications of the subprime/foreclosure crisis, as it grinds on, will affect femaleheaded households with disproportionate force, within the already-racialized landscape of networth destruction. In any era of a shrinking public "safety net", the implications for women's welfare are dire.

But beyond the differential impacts that this already implies for women as a result of the current crisis, two other implications of our analysis should be highlighted. One derives from the decreasing availability of detailed racial/ethnic data: less satisfactory public data is available on subprime mortgage lending than has been available on 'prime' lending; and no public data are collected on foreclosures. This empirical invisibility of race vis-a-vis the subprime crisis reinforces the analytical invisibility of race in economists' accounts of subprime lending and of the subsequent foreclosure crisis; and both trends reinforce the invisibility of race in policy debate. Turning the invisible visible depends on showing how racial/ethnic inequality-or gender inequality-compromises social reproduction, destroys wealth, and contributes to economically inefficient social outcomes.

Second, one must be concerned about the broader implications of a lightly regulated, market-power-possessing financial sector for women's participation in credit markets, and especially mortgage markets. For like minorities, women have less secure jobs, fewer assets, and more insecure prospects; their greater collective riskiness invites the creation of new exploitative lending instruments-especially now that the epidemic of subprime lending has run its course vis-a-vis minority communities. As Young and Schuberth (2010) point out, one distinctive feature of the current structure of management in megabanks is the dearth of women in positions of power. Profit-maximizing megabanks whose cartel-like behavior exploited and worsened racial inequality might move next to exploit the profit-taking potential in a gender cartel. 


\section{REFERENCES}

Aalbers, Manuel B. 2009. "Geographies of the Financial Crisis.” Area 41(1):34-42.

Acker, Joan. 2000. "Revisiting Class: Thinking from Gender, Race, and Organizations." Social Politics 7(2): 192-214. Summer.

Aldana, Carolyn, and Gary A. Dymski, 2004. "Urban Sprawl, Racial Separation, and Federal Housing Policy." In Jennifer Wolch, Manuel Pastor, Jr. and Peter Dreier eds., Up Against the Sprawl: Public Policy and the Making of Southern California,). Minneapolis University of Minnesota Press. 99-119.

Austin Turner, Margery, Stephen L. Ross, George C. Galster, and John Yinger. 2002. Discrimination in Metropolitan Housing Markets: National Results from Phase I HDS 2000 -- Final Report. Washington, DC: Urban Institute. November.

Avery, Robert B., Patricia E. Beeson, and Mark S. Sniderman. 1994. "Underserved Mortgage Markets: Evidence from HMDA Data.” Working Paper 9421. Federal Reserve Bank of Cleveland. December.

Avery, Robert B., Kenneth P. Brevoort, and Glenn B. Canner. 2006. "Higher-Priced Home Lending and the 2005 HMDA Data." Federal Reserve Bulletin 92 September: A123A166. 2007. "Higher-Priced Home Lending and the 2005 HMDA Data." Federal Reserve Bulletin 93: A73-A109 December.

Avery, Robert B., Neil Bhutta, Kenneth P. Brevoort, Glenn B. Canner, and Christa N. Gibbs. 2010a. "The 2008 HMDA Data: The Mortgage Market during a Turbulent Year." Federal Reserve Bulletin 96: A169-A211. April.

Avery, Robert B., Neil Bhutta, Kenneth P. Brevoort, and Glenn B. Canner. 2010b. "The 2009 HMDA Data: The Mortgage Market in a Time of Low Interest Rates and Economic Distress." Federal Reserve Bulletin 96: A1-A39. December.

Barth, J. R., Tong Li, T. Phumiwasana and Glenn Yago. 2008. "A Short History of the SubPrime Mortgage Market Meltdown.” GH Bank Housing Journal. Los Angeles. Milken Institute.

Barr, M. S. 2004. "Banking the Poor". Yale Journal on Regulation Vol. 21: 121-237 Winter.

Been, Vicki, Ingrid Ellen and Josiah Madar. 2009. "The High Cost of Segregation: Exploring Racial Disparities in High Cost Lending." Forthcoming, Fordham Urban Law Journal. Working Paper. Furman Center for Real Estate and Urban Policy, NYU School of Law/Wagner School of Public Service. November.

Bostic, Raphael W. 1996. "The Role of Race in Mortgage Lending: Revisiting the Boston Fed Study.” Division of Research and Statistics Working Paper. Washington, DC: Federal Reserve. 
Bradbury, Katherine L., Karl E. Case, and Constance R. Dunham. 1989. "Geographic Patterns of Mortgage Lending in Boston. 1982-87." New England Economic Review September/October: 3-30.

Bradford, Calvin. 2002. Risk or Race? Racial Disparities and the Subprime Refinance Market. Washington, DC: Center for Community Change.

Brooks, R. and Ruth Simon. 2007. “As Housing Boomed, Industry Pushed Loans to a Broader Market." Wall Street Journal A1. December.

California Reinvestment Coalition (CRC). 2010. Community Reinvestment Association of North Carolina, Empire Justice Center, Massachusetts Affordable Housing Alliance, Neighborhood Economic Development Advocacy Project, Ohio Fair Lending Coalition, Woodstock Institute. Paying More for the American Dream IV: The Decline of Prime Mortgage Lending in Communities of Color, May 2010. Accessed on February 1, 2011, at http://www.nedap.org/resources/documents/PayingMoreIV_Final.pdf.

Calomiris, Charles. 2008. "The Subprime Turmoil: What's Old, What's New, and What's Next." Working Paper. American Enterprise Institute. October.

Calomiris, Charles, Charles Kahn, and Stanley Longhofer. 1994. "Housing-Finance Intervention and Private Incentives: Helping Minorities and the Poor." Journal of Money, Credit and Banking 26(3) Part 2: Federal Credit Allocation: Theory, Evidence, and History. 634674. August.

Canner, Glenn B., and Wayne Passmore. 1994. "Residential Lending to Low-Income and Minority Families: Evidence from the 1992 HMDA Data." Federal Reserve Bulletin 80 79-108. February.

Caskey, John. 1996. Fringe Banking: Check-Cashing Outlets, Pawnshops, and the Poor. New York: Russell Sage Foundation.

Cooter, Robert. 1994. "Market Affirmative Action.” 31 San Diego Law Review 133. Winter.

Courchane, Marsha, Amos Golan, and David Nickerson 2000. "Estimation and Evaluation of Loan Discrimination-An Informational Approach.” Journal of Housing Research 11(1): 67-90.

Center for Public Integrity, The. "Who's Behind the Financial Meltdown? The Top 25 Subprime Lenders and their Wall Street Backers." 2011. Accessed on February 17, 2011, at http://www.publicintegrity.org/investigations/economic_meltdown/the_subprime_25/.

Crump, Jeff, Kathe Newman, Eric S. Belsky, Phil Ashton, David H. Kaplan, Daniel J. Hammel and Elvin Wyly. 2008. "Cities Destroyed (Again) for Cash: Forum on the U.S. Foreclosure Crisis.” Urban Geography 29(8): 745-784. 
Darity, William, 1989. "What's Left of the Economic Theory of Discrimination?" In Steven Shulman and William Darity, Jr.eds., The Question of Discrimination: Racial Inequality in the US Labor Market. Middletown, CT: Wesleyan University Press.

Dixit, Avinash K., and Joseph E. Stiglitz, 1977. "Monopolistic Competition and Optimum Product Diversity." American Economic Review 67(3): 297-308.

Dymski, Gary A. 2006b. "Discrimination in the Credit and Housing Markets: Findings and Challenges 2006." In William Rodgers. (ed.). Handbook on the Economics of Discrimination Cheltenham, UK: Edward Elgar. 215-259.

Dymski, Gary A. 2010. "The Global Crisis and the Governance of Power in Finance." In Philip Arestis, Rogério Sobreira, and José Luís Oreiro eds., The Financial Crisis: Origins and Implications. London: Palgrave-Macmillan. 63-86.

Dymski, Gary A., and Lisa Mohanty. 1999. "Credit and Banking Structure: Asian and AfricanAmerican Experience in Los Angeles." American Economic Review Papers and Proceedings 89(2): 362-6. May.

Dymski, Gary A., and John M. Veitch. 1996. "Financial Transformation and the Metropolis: Booms, Busts, and Banking in Los Angeles." Environment and Planning A28(7): 12331260. July.

Elliott, Douglas J., and Martin Neil Baily. 2009. "Telling the Narrative of the Financial Crisis: Not Just a Housing Bubble." Brookings Institution, November 23, 2009. Accessed on January 27, 2011 at www.brookings.edu/papers/2009/1123_narrative_elliott_baily.aspx.

Elson, Diane. 1994. "Micro, Meso, Macro: Gender and Economic Analysis in the Context of Policy Reform.” In I. Bakker (ed.) The Strategic Silence: Gender and Economic Policy. London: Zed Books.

Farmer, Roger. 2010. Expectations, Employment, and Prices. Oxford: Oxford University Press.

Financial Crisis Inquiry Commission (FCIC). 2011. The Financial Crisis Inquiry Report. Washington, DC:US Government Printing Office. January.

Fender, Ingo and Janet Mitchell. 2005. "Risk, Complexity, and the Use of Ratings in Structured Finance.” Working Paper. Bank for International Settlements and National Bank of Belgium. March.

Fishbein, Allen J., and Patrick Woodall. 2006. "Women are Prime Targets for Subprime Lending." Consumer Federation of America Washington, DC. December.

Gerardi, Kristopher, Andreas Lehnert, Shane M. Sherland, and Paul S. Willen. 2008. "Making Sense of the Subprime Crisis." Brookings Papers on Economic Activity 69-159. Fall. 
Gerardi, Kristopher, Harvey S. Rosen and Paul Willen. 2007. "Do Households Benefit from Financial Deregulation and Innovation? The Case of the Mortgage Market." National Bureau of Economic Research Working Paper 12967. National Bureau of Economic Research. Cambridge, MA. March.

Gerardi, Kristopher, and Paul Willen. 2009. "Subprime Mortgages, Foreclosures, and Urban Neighborhoods.” Working Paper 2009-1. February. Federal Reserve Bank of Atlanta.

Goolsbee, Austan. 2007. “'Irresponsible' Mortgages Have Opened Doors to Many of the Excluded." New York Times C3. March 29.

Greenspan, A. 2010. Written testimony for the Financial Crisis Inquiry Commission, hearings on "Subprime Lending and Securitization and Government-sponsored Enterprises (GSEs)." Day 1, Session 1. The Federal Reserve. April 7.

Hernandez, Jesus. 2009. "Redlining Revisited: Mortgage Lending Patterns in Sacramento 19302004." International Journal of Urban and Regional Research 33(2): 291-313. June.

Holmes, Andrew, and Paul Horvitz. 1994. "Mortgage Redlining: Race, Risk, and Demand." Journal of Finance 49(1): 81-99. March.

Housing and Urban Development (HUD) 2000. Department of, Unequal Burden: Income and Racial Disparities in Subprime Lending in America. Washington, DC: Department of Housing and Urban Development. April.

Hudson, M. 2010. The Monster: How a Gang of Predatory Lenders and Wall Street Bankers Fleeced America - and Spawned a Global Crisis. New York: Holt, Henry and Company.

Hunter, William C. and Mary Beth Walker. 1996. "The Cultural Affinity Hypothesis and Mortgage Lending Decisions." Journal of Real Estate Finance and Economics 13: 5770.

Immergluck, Dan. 2008. "From the Subprime to the Exotic: Excessive Mortgage Market Risk and Foreclosures." Journal of the American Planning Association 74(1): 59-77 Winter.

Immergluck, Dan, Manuel Aalbers and Peter Marcuse,. 2009. "A Symposium on the Subprime Crisis." City and Community 8(3): 341-56. September.

Immergluck, Dan, and Geoff Smith. 2006. "The External Costs of Foreclosure: The Impact of Single-Family Mortgage Foreclosures on Property Values.” Housing Policy Debate 17:1: 57-80.

Laderman, Elizabeth, and Carolina Reid. 2008. "Lending in Low- and Moderate-Income Neighborhoods in California: The Performance of CRA Lending During the Subprime Meltdown.” Working Paper 2008-05. Federal Reserve Bank of San Francisco. November. 
Lewis, Michael. 2010. The Big Short: Inside the Doomsday Machine. New York: W.W. Norton.

McCoy, Patricia and Elvin Wyly. 2004. "Special Issue on Market Failures and. Predatory Lending." Housing Policy Debate 15(3).

Mian, Atif, and Amir Sufi. 2008. "The Consequences of Mortgage Credit Expansion: Evidence from the 2007 Mortgage Default Crisis.” Mimeo. University of Chicago Graduate School of Business. January.

Mollencamp, C., Edward Taylor and Ian McDonald. 2007. "How the Subprime Mess Ensnared German Bank; IKB Gets a Bailout.” Wall Street Journal A1. August 10.

Munnell, Alicia H., Lynn E. Browne, James McEneaney, and Geoffrey Tootell. 1992. Mortgage Lending in Boston: Interpreting HMDA Data. Working Paper No. 92-7. Boston: Federal Reserve Bank of Boston.

Office of the Comptroller of the Currency. 2010. "Comptroller Dugan Testifies before the FCIC." April 8, 2010. Washington, DC. Accessed on February 17, 2011 at http://www.occ.treas.gov/news-issuances/news-releases/2010/nr-occ-2010-39.html.

Omi, Michael. 2001. "The Changing Meaning of Race.” In Neil J. Smelser, Julius Wilson and Faith Mitchell, eds., America Becoming: Racial Trends and Their Consequences. Washington, DC: National Academy Press. 243-263.

Orozco, Manuel. 2004. The Remittance Marketplace: Prices, Policy, and Financial Institutions. Washington, DC: Pew Hispanic Center.

Quigley, John M. 2008. "Compensation and Incentives in the Mortgage Business. Economists' Voice October.

Partnoy, Frank and David A. Skeel. Jr. 2007. "The Promise and Perils of Credit Derivatives." University of Cincinnati Law Review (75)2: 1027. Spring.

Reinhart, Carmen, and Kenneth Rogoff. 2009. This Time is Different: Eight Centuries of Financial Folly. Princeton: Princeton University Press.

Roithmayr, Daria. 2007. "Racial Cartels." Law and Economics Working Paper Series. Paper 66. University of Southern California Law School.

Ross, Stephen L., and John Yinger. 1999. "Does Discrimination in Mortgage Lending Exist? The Boston Fed Study and Its Critics." Chapter 3. In Austin Turner, Margery, and Felicity Skidmore eds., Mortgage Lending Discrimination: A Review of Existing Evidence Washington, DC: Urban Institute June: 45-83.

Rugh, Jacob S., and Douglas S. Massey. 2010. "Racial Segregation and the American Foreclosure Crisis.” American Sociological Review 75(5): 629-651. 
Schloemer, Ellen, Wei Li, Keith Ernst, and Kathleen Keest. 2006. "Losing Ground: Foreclosures in the Subprime Market and Their Cost to Homeowners." Center for Responsible Lending Washington, DC. December.

Shadow Financial Regulatory Committee. 2001. "Statement of the Shadow Financial Regulatory Committee on Predatory Lending." American Enterprise Institute. Statement No. 173. Washington, DC. December 3.

Shiller, Robert J. 2008. The Subprime Solution. Princeton: Princeton University Press.

Sorkin, A. R. Too Big to Fail" 2009. The Inside Story of How Wall Street and Washington Fought to Save the Financial System---and Themselves. New York: Viking.

Spence, Michael. 1974. Market Signaling: Informational Transfer in Hiring and Related Screening Processes. Cambridge: Harvard University Press.

Squires, Gregory D., Derek S. Hyra, and Robert N. Renner. 2009. "Segregation and the Subprime Crisis.” EPI Briefing Paper \#244. Washington, DC: November 4.

Stiglitz, Joseph E. 1987. "The Causes and Consequences of the Dependence of Quality on Price." Journal of Economic Literature 25(1) March: 1-48.

Stiglitz, Joseph E., and Andrew Weiss. 1981. "Credit Rationing in Markets with Imperfect Information." American Economic Review 71(3): 393-410. June.

Young, Brigitte, and Helene Schuberth. 2010. "The Global Financial Meltdown and the Impact of Financial Governance on Gender," GARNET Policy Brief No. 10, January. GARNET Network of Excellence, University of Warwick.

Wallison, Peter J. 2009. "The True Origins of This Financial Crisis," American Spectator, February.

Williams, Rhonda. 1991. If You're Black, Get Back; If You're Brown, Stick Around; If You're White, Hang Tight: A Primer on Race, Gender, and Work in the Global Economy. Department of Afro-American Studies, University of Maryland, College Park. Mimeograph.

Williams, Richard, Reynold Nesiba, and Eileen Diaz McConnell. 2005, "The Changing Face of Inequality in Home Mortgage Lending." Social Problems 52: 181-208.

Wray, L. Randall. 2008. "Financial Markets Meltdown: What Can We Learn from Minsky?" Public Policy Brief No. 94. Annandale-on-Hudson, NY: Levy Economics Institute of Bard College.

Wyly, Elvin K., Mona Atia, Holly Foxcroft, Daniel J. Hammel and Kelly Phillips-Watts. 2006. "American Home: Predatory Mortgage Capital and Neighborhood Spaces of Race and Class Exploitation in the United States." Geografiska Annaler 88 B: 105-32. 
Wyly, Elvin K., Mona Atia, Elizabeth Lee, and Pablo Mendez. 2007. "Race, Gender, and Statistical Representation: Predatory Mortgage Lending and the US Community Reinvestment Movement." Environment and Planning A 39: 2139-66.

Wyly, Elvin K., and Steven R. Holloway. 2002. "The Disappearance of Race in Mortgage Lending." Economic Geography 78(2): 129-69. April.

Wyly, Elvin K., Marcus Moos, Holly Foxcroft, and Emmanuel Kabahizi. 2008. "Subprime Mortgage Segmentation in the American Urban System." Tijdschrift voor Economische en Sociale Geografie 99(1): 3-23. 